East Tennessee State University

Digital Commons@ East Tennessee State University

ETSU Faculty Works

Faculty Works

$12-1-2015$

\title{
Understanding the Essex Junto: Fear, Dissent, and Propaganda in the Early Republic
}

Dinah Mayo-Bobee

East Tennessee State University, mayobobee@etsu.edu

Follow this and additional works at: https://dc.etsu.edu/etsu-works

Part of the Political History Commons, and the United States History Commons

\section{Citation Information}

Mayo-Bobee, Dinah. 2015. Understanding the Essex Junto: Fear, Dissent, and Propaganda in the Early Republic. The New England Quarterly. Vol.88(4). 623-656. https://doi.org/10.1162/TNEQ a_00493 ISSN: 0028-4866

This Article is brought to you for free and open access by the Faculty Works at Digital Commons @ East Tennessee State University. It has been accepted for inclusion in ETSU Faculty Works by an authorized administrator of Digital Commons @ East Tennessee State University. For more

information, please contact digilib@etsu.edu. 


\section{Understanding the Essex Junto: Fear, Dissent, and Propaganda in the Early Republic}

\section{Copyright Statement}

(C) 2015 by The New England Quarterly. MIT Press Journals permits authors to archive the final version of record of their article on institutional repositories and personal webpages hosted at the institution. This document was originally published by The New England Quarterly. 


\title{
Understanding the Essex Junto: Fear, Dissent, and Propaganda in the Early Republic
}

\author{
DINAH MAYO-BOBEE
}

$\mathrm{O}$ N 7 February 18o9, Thomas Jefferson condemned Congress for voting "in a panic" to repeal the embargo that his administration laid on all shipping in 1807. The government's prohibitions on the maritime and overland trades, along with draconian methods of enforcement provoked intense, sometimes violent opposition in New England. When he expressed his aggravations to his son-in-law, former congressman Thomas Mann Randolph (Va.), Jefferson had less than a month remaining in office. Yet, despite the fact that the embargo would be lifted after he left office, he found New Englanders' resistance to the law and threats of disunion vexing. In his opinion, the Essex Junto, an unpatriotic and diabolical political group operating out of Massachusetts, had orchestrated the "forcible opposition" that ruined the embargo's success along with his last days in office. ${ }^{1}$

Jefferson's attribution of the failure of his controversial policy to one of the era's most denounced factions did little to define the Essex Junto or cement its place in history. For the

Dr. Mayo-Bobee wishes to thank the American Antiquarian Society, Philips Library at the Peabody Essex Museum, Massachusetts Historical Society, Filson Historical Society, Library of Congress, the W.E.B. Dubois Library at the University of Massachusetts Amherst, and the Charles C. Sherrod Library at East Tennessee State University.

${ }^{1}$ Thomas Jefferson to Thomas Mann Randolph Jr., 7 February 1809, Thomas Jefferson Papers 1606-1827, Library of Congress http://memory.loc.gov/ammem /collections/jefferson_papers/ (Accessed 18 July 2015) hereafter referred to as Jefferson Papers.

The New England Quarterly, vol. LXXXVIII, no. 4 (December 2015). (C) 2015 by The New England Quarterly. All rights reserved. doi:10.1162/TNEQ_a_oo493. 
most part scholars agree with Jefferson's analysis despite David H. Fischer's article, "The Myth of the Essex Junto." Fischer attempted to dispel the notion that ambitious Federalists from Essex County controlled Federalist Party politics. Fisher argued that there was not even a single faction of conspirators in control of Massachusetts politics after the 1750s. Indeed, many of the Federalists historically associated with the junto, including Stephen Higginson and George Cabot of Salem, Francis Dana and Theophilus Parsons of Boston, and John Lowell of Newburyport had retired from public life by 1796. By the time Jefferson sent his complaints to Randolph, the term, Fischer argues, had become little more than a "universal pejorative," uttered as an abstract "symbol of depravity, a synonym for sin."

In the decades following the publication of Fischer's article, scholars of early national politics have found it difficult to dismiss the Essex Junto as myth because the term appears so frequently in the correspondence, speeches, literature, and debates of the period. Although some historians unceremoniously omit any discussion of the Essex Junto, others feel compelled to at least mention or provide succinct, albeit vague definitions. Scholars have depicted the Essex Junto as either an ultra-conservative wing of New England Federalists, a faction of North Shore Federalists, elite politicians operating within Massachusetts's Federalist Party, or a broadly based group of Federalist activists whose disruptive influence was national in scope. ${ }^{3}$ Any attempt to construct a definitive description or conclusive interpretation is complicated by the fact that original references to the Essex Junto are ambiguous and appear in

\footnotetext{
${ }^{2}$ David Hackett Fischer, "The Myth of the Essex Junto," The William and Mary Quarterly $3^{\text {rd }}$. ser, 21 (April 1964): 191-95, 224, 235 (hereafter referred to as WMQ).

${ }^{3}$ James M. Banner Jr., To the Hartford Convention: The Federalists and the Origins of Party Politics in Massachusetts, 1789-1815 (New York: Alfred A. Knopf, 1970), p. 219; Ronald M. Peters, Jr., The Massachusetts Constitution of 1780: A Social Compact (Amherst: The University of Massachusetts Press, 1978), pp. 30, 31; Marc M. Arkin, "The Force of Ancient Manners: Federalist Politics and the Unitarian Controversy Revisited," Journal of the Early Republic 22 (Winter 2002): 580, 601, 609 (hereafter referred to as JER); and Johann N. Neem, Creating a Nation of Joiners: Democracy and Civil Society in Early National Massachusetts (Cambridge, 2008), p. 62.
} 
political propaganda and debates long after the Federalist Party disbanded in the $\mathbf{1 8 2 0 s}$. Another barrier to reaching an interpretive consensus is the inconsistent geographic and political orientation of assumed junto politicians. These discontinuities make it almost impossible to draw a solid conclusion about the Essex Junto, but it is also true that when they "used the term whether seriously or in jest," as Fischer asserted, Americans "understood broadly to whom the term applied."4

To understand the Essex Junto, its meaning in political rhetoric, and frequent appearance in political propaganda, this article looks at the evolution of the term that eventually, almost naturally, transcended its association with Massachusetts Federalists. Analyzing developments that shaped perceptions about what the term represented, why it was used, and to whom it applied gives us a better grasp of the Essex Junto and its significance in political discourse from the end of the Revolution through the antebellum period. Accomplishing this goal requires approaching the topic with a new set of assumptions while assessing expanded meanings of the Essex Junto over time.

At the nation's founding, political leaders were afraid that secret organizations similar to the subversive factions that corrupted European nations would destroy the new republic. As soon as representatives from diverse and previously isolated regions of the country met in Congress for the first time, many condemned what they saw as the formation of clandestine alliances or "political combinations" among legislators. Congressmen began to circulate rumors that a few representatives were meeting secretly and conspiring to promote or block specific legislation with sinister intentions. Aghast that dangerous cabals had formed in New Jersey, Virginia, Pennsylvania and other states, representatives Richard Henry Lee (Va.), Francis Lightfoot Lee (Va.), and John Collins (R.I.), issued warnings that similar factions were perpetrating mischief in the national legislature.

\footnotetext{
${ }^{4}$ Fischer, "Myth of the Essex Junto," p. 225; Arkin, "Force of Ancient Manners," p. $5^{80 \mathrm{on}}$.
} 
In 1774, reports that a junto, "mostly of New England men," had formed a powerful voting bloc and had identified a specific threat to republican government. Rhode Island's David Howell complained about the "hood-winking . . . hugger-mugger" processes that this junto employed to advance a policy agenda that would usurp the will of the people. Five years later, a letter repeating this charge appeared on the front page of The Pennsylvania Evening Post. Credited to Representative Edward Langworthy (Ga.), the letter publicized the creation of a New England junto during the First Continental Congress, and informed the public that the group met "regularly . . . to keep back or obstruct any measure whatever."

This indictment compelled Oliver Ellsworth (Conn.) to defend himself and fellow New Englanders in the Connecticut Courant. First, Ellsworth dismissed Langworthy's charge that Congress was "ass-ridden with a junto" as unsubstantiated propaganda. Next, after affirming that no evidence existed to validate the allegation, Ellsworth said it was astonishing that in five years this group of conspirators "has to this day been kept a profound secret." Stephen Higginson (Mass.) joined Ellsworth in his effort to quash rumors that New Englanders were conspiring to establish aristocratic rule. Higginson and Ellsworth mounted a plausible defense, but detractors continued to publish articles that reinforced anxieties over factions. Few Americans apparently took the New Englanders' claims of innocence seriously. ${ }^{6}$

Once respected politicians tied New Englanders to political intrigue, they opened the door for conspiracy theorists to target Massachusetts' political leaders. Massachusetts was the largest

5John Adams to Hugh Hughes, 4 June 1776 and Samuel Adams to James Warren, 16 April 1776; Richard Henry Lee to Arthur Lee, 24 February 1775, Francis Lightfoot Lee to Arthur Lee, 22 April 1779, William Shippen to Richard Henry Lee, 22 June 1779, John Collins to Nathaniel Green 7 September 1779, and David Howell to unknown recipient, 28 July 1783 , and R.I. Delegates to William Green, 8 September 1773 , in Letters of Delegates to Congress, 1774-1789, edited by Paul H. Smith, et al., (26 vols. Washington, D.C., 1979), 1: 313, 3: 11, 359, 6:134-35, 12: 369, 13:100, 467, and 20: 472; Pennsylvania Evening Post, 9 July 1779.

${ }^{6}$ Jesse Root to Oliver Ellsworth, 8 September 1779, Stephen Higginson to Theodorick Bland and Elbridge Gerry, 6 October 1783, Letters of Delegates, 13: 478-79, 21: 26, 23; Connecticut Courant 10 August 1779. 


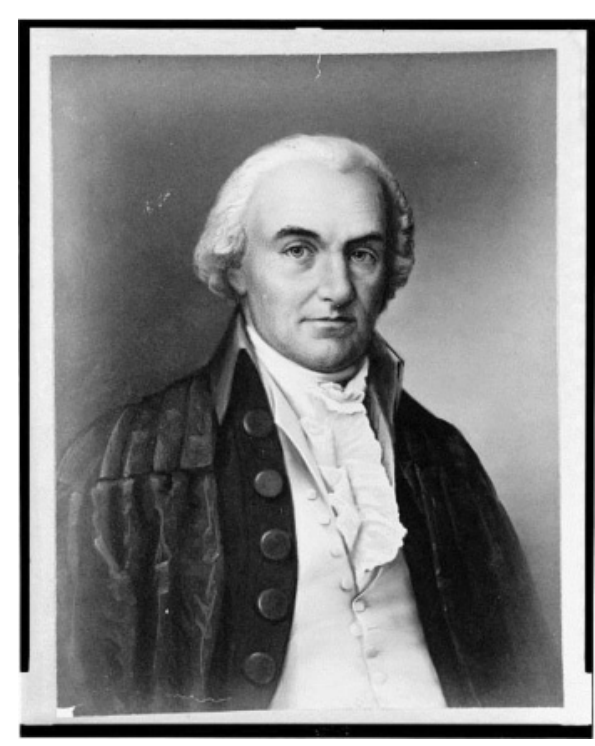

Oliver Ellsworth (1745-1807)

Ellsworth of Connecticut, a delegate to the Continental Congress and Constitutional Convention of 1787 , US Senator, and Chief Justice of the Supreme Court (1796-180o) defended fellow New Englanders against allegations that they were conspiring to take control of the nation. Courtesy of the U.S. Senate Historical Office, Library of Congress.

and most radical colony at the start of the Revolution, and both John and Samuel Adams were forced to temper their passions for independence because so many in the Continental Congress mistrusted their motives. To avoid risking the Patriot cause, Samuel Adams recommended proposing their ideas "by means of other persons." The cousins decorated the background while Virginians advanced their strategies. Through the use of surrogates, they shrewdly eased the trepidations of many who were reluctant to sever ties with Britain or join a confederation of states if it was led by Massachusetts. ${ }^{7}$

${ }^{7}$ Adams quoted in John Ferling, A Leap in the Dark: The Struggle to Create the American Republic, (New York: Oxford University Press, 2003), pp. 114, 115; Theophilus Parsons to John Waite, Esq., 19 March 1776 in Theophilus Parsons, Memoir 
Instead of dispelling doubts that other states had about Massachusetts, however, distrust of the state's representatives became more pronounced after independence. In fact, personality clashes, competing economic interests, and policy disputes even created divisions and an air of uneasiness within the state. In 1781 , his final year in Congress, Samuel Adams cautioned voters to exercise the franchise diligently and carefully in order to avert the collusions of a junto trying to "change the love of liberty into the spirit of faction." "Within a decade of Adams's warning, politicians in his state and across the nation would subscribe to the notion that the source of anti-democratic, antirepublican schemes was a junto based in Essex County.

Essex was not chosen randomly. In 1776, county leaders had complained that wealth should entitle them to more representation in the state legislature. Two years later, after the General Court drafted a new state constitution and sent it to the counties for approval, Essex prepared a point-by-point critique of the proposed government. At irregular intervals, "The Essex Result," proposed revisions such as a bill of rights, but more often, it digressed into a treatise on government praising political equality but reserving governance for "gentlemen of education, fortune, and leisure."9

Revolutionaries in Massachusetts found the rationalization for rule by a "natural aristocracy" disconcerting. Essex County spokesmen were not Loyalists, but their views reflected Toryism nonetheless. Claims that factions in and around Boston favored social stratification and royalist pretensions seemed irrefutable. Theophilus Parsons's son theorized that the Essex Result was, "one of the grounds-perhaps the chief one-for that nickname of 'The Essex Junto.'” Parsons, who is credited with

of Theophilus Parsons Chief Justice of the Supreme Judicial Court of Massachusetts (Boston: Ticknor and Fields, 1859), p. 40.

${ }^{8}$ Samuel Adams to the Public, 13 March 1781, Letters to Delegates, 27: 56; Massachusetts Centinel 18 and 25 May 1785; Independent Chronicle 24 March 1785; Banner, Hartford Convention, pp. 123, 124.

9"Essex County Convention, Ipswich, 25 and 26 April 1776, and "The Essex Result, 1778," in Oscar and Mary Handlin, The Popular Sources of Political Authority: Documents on the Massachusetts Constitution of 1780 (Cambridge: The Belknap Press of Harvard University Press, 1966), pp. 73-75, 324-65. 
writing the Essex Result, was as proud of the sobriquet as "of any political distinction" and accordingly "held on to it to the end of his life." 10

Between the end of war in 1783 and the Constitutional Convention of 1787 , factions in Massachusetts were on the verge of maturing into political parties. Perhaps the most meaningful indication of this was the breakdown of civil order during the postwar economic downturn. As the maritime interests in the coastal areas toyed with protective tariffs, agriculturalists in the west lacked a similar plan for economic recovery. When the General Court rejected efforts to pass debt relief, farmers questioned the governor's high salary, as well as the profits earned by costal investors and speculators at the same time that they faced imprisonment and confiscation of their property when they could not pay their taxes. Distrust for the leadership in Boston, monetary reforms that exacerbated their financial distress, and heavy handed tax collecting tactics, sparked rebellions led by Samuel Ely and Daniel Shays in 1782 and 1786-87 respectively. ${ }^{11}$

Symptomatic of a larger, national problem, the solution among elites was a stronger central government under a new constitution. Yet, just as they had resisted the centralized authority in Boston, western agriculturalists opposed ratification in 1788. By some estimates, the Antifederalist opponents of ratification in Massachusetts outnumbered the Constitution's Federalist supporters. Furthermore, the Antifederalists' apprehensions were strengthened by revolutionary leader Samuel Adams's initial objection to ratification. Most likely, they also recalled that only a few years earlier Adams warned them about junto plots to destroy the republic and democratic freedoms. To Adams the new Constitution did just that. ${ }^{12}$

\footnotetext{
${ }^{10}$ Parsons, Memoir, p. 48 .

${ }^{11}$ Roger H. Brown, Redeeming the Republic: Federalists, Taxation, and the Origins of the Constitution (Baltimore: Johns Hopkins University Press, 1993), pp. 108-21, 132, 137; Woody Holton, Unruly Americans and the Origins of the Constitution (New York: Hill and Wang, 2007), pp. 31, 32, 38, 88.

${ }^{12}$ See Ferling, A Leap in the Dark, pp. 296-301; Jack N. Rakove, Original Meanings: Politics and Ideas in the Making of the Constitution (New York: First Vintage Books Edition, 1997), pp. 119-21.
} 
The Antifederalists' influence waned after John Hancock announced his support for ratification at the same time that Federalists manipulated the press and issued fabricated endorsements to increase popular support for the Constitution. Following ratification, fears that the proponents of big government would surreptitiously establish an aristocracy were reignited when voters sent a Federalist majority to Congress. Treasury Secretary Alexander Hamilton's economic plans, couched in open admiration for the British, contributed to this perception and the formation of the Democratic-Republican Party with its unyielding condemnation of Federalists and the suppression of their party. ${ }^{13}$

The new party frequently criticized Federalists in the partisan press for Hamilton's Anglophile economics, Jay's treaty with Britain, and the Alien and Sedition Acts. Following Jefferson's lead, Democratic-Republicans wrote or hired others to write damaging, sometimes incendiary, articles that censured the Essex Junto for trying "to sap the republic by fraud, if they cannot destroy it by force, \& to erect an English monarchy in it's [sic] place." Federalist Party support began to atrophy in the South because of the Essex Junto and New England Federalists' calls to repeal the three-fifths clause, the Constitution's provision for counting slaves in the calculation for congressional representatives. But Federalists also faced challenges in the New England and the Mid-Atlantic states because of their identification with the pro-British, antidemocratic Essex Junto. In Massachusetts Democratic-Republicans implemented Jefferson's struggle to "strip of all the means of influence the Essex junto, \& their associate monocrats." 14

Through the 179os, the Essex Junto applied narrowly to Massachusetts Federalists who were considered the enemies of democracy. Most were aware of the damage that this image

${ }^{13}$ Massachusetts Centinel, 7 March 1789; Ferling, Leap in the Dark, pp. 300, 307; David Hackett Fischer, The Revolution of American Conservatism: The Federalist Party in the Era of Jeffersonian Democracy (New York: Harper \& Row, 1965), p. 249; Boston Gazette, 2 and 23 March 1789; Herald of Freedom, 20 March 1789; Boston Constitutional Telegraphe, 12 April 1800.

${ }^{14}$ Thomas Jefferson to Levi Lincoln, 11 July 1801, Jefferson Papers. 
was inflicting on their party. Former Congressman Fisher Ames of Dedham, Massachusetts made glib references to this problem in a letter dated 16 February 1801. To Jeremiah Smith, Ames wrote facetiously, "thank you for early asking my influence, which as one of the Essex Junto, you know is great." Not intending for Smith to take his reference seriously, he added sardonically, "It is bold of you, sinner that you are, to ask any thing of me." Ames was not from Essex County and had retired from Congress in 1796 because of a chronic, debilitating respiratory ailment. Ames vacillated over the Federalist Party's ability to reclaim power after losing the presidency and Congress in 1800 , but his moments of doubt were well founded. Ames belied stories of the Essex Junto's influence when criticizing his party's lack of unity. "Party is an association of honest men for honest purposes ... But the federalists [sic] are scarcely associated" Ames admitted. He was sure that it would take individual perseverance to "prevent the dissolution of the feeble ties by which the federal party is held together."15

Before writing his tongue-in-cheek letter to Smith, Ames discussed the gap between perceptions about an Essex Junto and its actual political influence as the Federalists' squabbled over John Adams's reelection in 1800 . He correctly predicted that Adams's supporters would blame the amorphous junto instead of Democratic-Republicans for losing the election and urged Hamilton to avoid "dividing the party" by supporting Adams. Despite rumors that he led the Essex Junto, Ames could not keep Hamilton from attempting to destroy Adams's chances for reelection. Even as trade restrictions began to raise the ire of New England's mariners in 1806, Ames had to urge congressional Federalists to participate in debates over the future of commerce. Any influence that Ames had was severely limited. Nevertheless, years after his death in 1808 , political enemies were still calling Ames the "oracle of the Essex Junto."16

\footnotetext{
${ }^{15}$ Ames to Thomas Dwight 15 August 1800 , Ames to Jeremiah Smith 16 February 1801, Ames to Theodore Dwight 19 March 1801, Fisher Ames, Works of Fisher Ames: With a Selection From His Speeches and Correspondence, ed. Seth Ames, 2 vols. (New York: Da Capo Press, 1969), 1:28o, 292, 293.

${ }^{16}$ John W. Malsberger, "The Political Thought of Fisher Ames," JER 2 (Spring, 1982): 10, 11; Ames to Alexander Hamilton, 26 August 180o, Ames to Josiah Quincy, 19
} 
Unlike Ames most Federalists were not cavalier about being associated with the Essex Junto. In the heated political climate of the late 1790 and early 1800 s, some of them tried to stem the tide of accusations that they were part of a conspiracy to overthrow the government. They struck back, claiming that their political opponents had created this imaginary junto and issued baseless accusations in order to exploit the public's fear of plots and intrigues. ${ }^{17}$ But Democratic-Republicans continued to inspire fear with skill and success through propaganda. Characterizing Federalists as threats to the Union also helped Jeffersonians win elections.

Propaganda was not the only problem that affected Federalists at the polls. From 1788 through 1800 , their elitism and cliquishness compounded accusations of aristocratic designs. Federalists spouted elitist viewpoints in public but privately differed little from their Democratic-Republican opponents. Members of both parties exchanged ideas about policy and strengthening the republic, partnered in business, intermarried, and promoted the wealthy, well-versed for political office. The most notable exception was Timothy Pickering, an Essex County politician who actually did devise a plan for disunion. A former secretary of state, U.S. senator, and representative, Pickering opposed the three-fifths clause and said that it was in New England's best interests to form a republic separate from the slave states. Convinced that New England could do "nothing to countervail the power and influence arising from the Negro representation," Pickering calculated that if Massachusetts, "the most powerful" state took the lead the rest of New England, followed by the Mid-Atlantic States would secede and then form a Northern Confederation free

\footnotetext{
March 1806, and Ames to Timothy Pickering, 24 March 1806, in Ames, Works, 1:28081, 371-72, 373-74 and 2:204-10, 322-34; Salem Gazette 18 July 180o; Newburyport Herald 25 July 180o, Windsor Vermont Republican, 7 April 1817; and Boston Patriot, 27 May 18og. Fischer, "Myth of the Essex Junto," pp. 195, 196, 211.

${ }^{17}$ Fischer, "Myth of the Essex Junto," p. 192; Richard Hofstadter, The Paranoid Style in American Politics and Other Essays (New York: First Vintage Book Edition, 2008), pp. 10, 12-14; Lance Banning, The Jeffersonian Persuasion: Evolution of a Party Ideology (Ithaca: Cornell University Press, 1978), pp. 205, 286.
} 


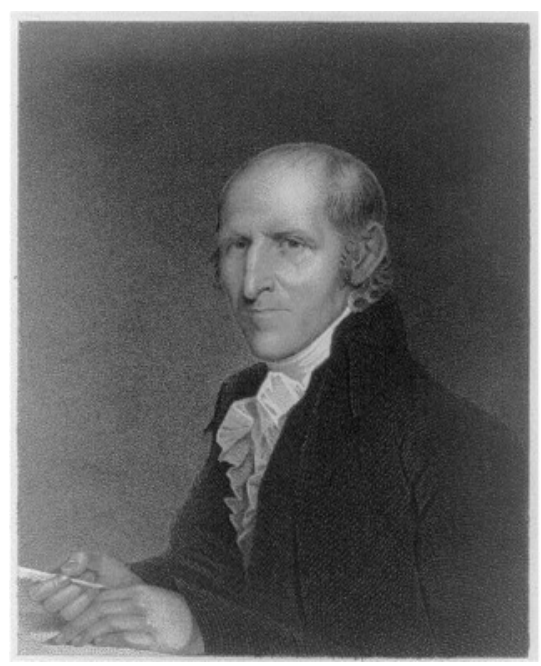

Timothy Pickering (1745-1829)

Pickering suggested that New England secede and form a Northern Confederacy because he opposed slave representation. He protested the embargo of 1807 and embraced a separate peace with Britain during the War of 1812. He was considered a leader of the Essex Junto. Courtesy of the U.S. Senate Historical Office, Library of Congress.

of slavery. ${ }^{18}$ His plan failed, but when Pickering's plans were exposed they confirmed what many Americans already believed-Essex County Federalists were still plotting to destroy the Union. No assertions to the contrary would erase this perception.

Despite Pickering's notoriety and the Federalist Party's damaged image, younger politicians were still attracted to it. Propagandists wasted no time linking newcomers, especially if they were outspoken, to the Essex Junto. Jeffersonian Benjamin Austin described the "Alarms, terror, threatening, and fraud" by which the junto "assailed the good sense of the people."

${ }^{18}$ Timothy Pickering to George Cabot, 29 January 1804, Pickering Papers, Massachusetts Historical Society, Boston, Mass.; Kevin M. Gannon "Escaping Mr. Jefferson's Plan of Destruction': New England Federalists and the Idea of a Northern Confederacy, 1803-1804" JER 21 (Autumn 2001): 413-16. 
Like other secret societies the junto's “choice spirits" recruited members and inducted them into their organization with secret rituals while "sycophants" intimidated "the lower class of the community." Austin said he could prove that this "selfaggrandizing faction" was responsible for "all the virulence of parties ... including ocean massacres, illuminati, \&c."19 When Federalists began to protest trade restrictions during Jefferson's second term, to onlookers they confirmed association with the Essex junto. Indeed, opposition to Democratic-Republican legislation became the litmus test for membership in the Essex Junto. When resistance to their policies surfaced outside of Massachusetts, Jeffersonians explained that the junto had grown powerful enough to influence people in Connecticut, Delaware, Maryland, and North Carolina. ${ }^{20}$

Federalists could not dispel the public's perceptions or create a comparable bête-noir to challenge Democratic-Republicans. During the French Revolution they accused DemocraticRepublicans of participating in a Bavarian Illuminati conspiracy to topple the US government. The effort failed, because as historian Gordon Wood explains, "throughout the 179os the Republicans had accused them of just this sort of deception." Federalists charges that a Democratic-Republican conspiracy was afoot looked retaliatory and inane coming from politicians linked to the Essex Junto. In the end the charges gained no traction. ${ }^{21}$

On the other hand, Democratic-Republicans had found that generating panic over secret plots was an extremely effective way to chisel away at the Federalist support base while they were in power. Once Federalists were voted out of power

\footnotetext{
${ }^{19}$ Benjamin Austin, Constitutional Republicanism, in Opposition to Fallacious Federalism (Boston: Adams \& Rhoades, 1803), pp. 16-17, 5 o.

${ }^{20}$ Fischer, "Myth of the Essex Junto," pp. 197, 199, 205, 235; William Sullivan, Familiar Letters of Public Characters and Public Events; From the Peace of 1783 to the Peace of 1815 (Boston: Russell, Odiorne, and Metcalf, 1834), pp. 97-99, 171; Charles Raymond Brown, The Northern Confederacy: According to the Plans of The "Essex Junto" 1796-1814 (Princeton: Princeton University Press, 1915), pp. 18, 19, $110-17$.

${ }^{21}$ Gordon S. Wood, "Conspiracy and the Paranoid Style: Causality and Deceit in the Eighteenth Century," WMQ $3^{\text {rd }}$ ser., 39 (Jul., 1982): 433-34.
} 
and relegated to minority status in Congress, DemocraticRepublicans continued to issue accusations about the junto to discredit any opposition message they might devise. For this reason during the Embargo of 1807 , instead of dealing with the economic causes of lawbreaking and protests, Jefferson and his party simply blamed the Essex Junto. ${ }^{22}$

Representations of monsters or grotesque figures in art and the "public mind," were, as one art historian argues, "a sign of political change." For this reason, caricatures of the Essex Junto began to surface most frequently during periods of political upheaval. In The Essex Junto; or Quixotic Guardian, a play published in 1802, J. Horatio Nichols personified the monstrous nature of the junto by dramatizing a fictional account of the Federalist Party to steal the presidency during Adams's final days in office. Nichols's title character in most scenes accompanies "Cockade" representing Federalists who, in connivance with "the Duke of Braintree" (Adams) plot to overthrow the federal government and keep "Monticello" (Jefferson) from becoming president. Beleaguered by mutual mistrust and internecine squabbling, the villains have problems executing their plan. When fellow conspirator, "General Creole" (the standing army) decides not to assassinate the "Old Patriot" (republican government), the plan falls apart. Eventually, Monticello and "Whig" (Jefferson's Democratic-Republican allies), thwart the coup d'état and save the republic. Deeply embedded corruption dooms Adams to obscurity and the Federalist Party to disgrace. Through it all, the title character remains undaunted. The Essex Junto, devoid of patriotism, virtue, or courage, vows to unleash an unrelenting barrage of venomous attacks on the Jefferson administration with "a scorpion's sting . . . [and] a frightful hissing." 23

\footnotetext{
${ }^{22}$ See Jefferson to Levi Lincoln, 11 July 1801; John Adams, 20 April 1812, 10 August 1815; John Melish, 13 January 1813; and William Short, 8 January 1825, Jefferson Papers; Merrill D. Peterson, Thomas Jefferson and the New Nation: A Biography (New York: Oxford University Press, 1970), pp. 913, 916-18.

${ }^{23}$ Wendy Bellion, "Patience Wright's Transatlantic Bodies," in Maurie D. McInnis and Louis P. Nelson, eds., Shaping the Body Politic: Art and Political Formation in Early America (Charlottesville: University of Virginia Press, 2011), pp. 37, 38; J. Horatio
} 
Nichols's understanding of political issues is evident in his treatment of the Quasi War, Adams's treaty with France, and the Jeffersonians' presumption that Federalists planned to seize power after the election of 1800 . On the other hand, Nichols links Federalists with every perceived threat to the Unionincluding slavery. He depicts Adams as a slave owner, Federalists as fugitive slave hunters who return the unfortunate to bondage, and Jefferson as an abolitionist. Despite its obvious mischaracterizations, however, the play correctly captures the internal disorganization that plagued the Federalist Party throughout its existence. ${ }^{24}$

Most importantly, "Essex Junto," though unpopular and permanently banished from the circles of power, would not let the nation prosper under Jeffersonian rule. When personified in this way, it was not necessary to provide details about junto policies or methods of operation. And while not depicted as physically grotesque, the character Essex Junto was unattractive, bellicose, and irrationally opposed to Jefferson's administration. This portrayal gave partisans in the press, Congress, and the literary world leave to disparage and dismiss any Federalist grievance as another divisive and sinister machination of the Essex Junto. ${ }^{25}$

Despite the ephemeral nature of such charges, each attack in the press put Federalists further on the defensive. Satirist Thomas Fessenden assailed the Democratic-Republican evocation of the Essex Junto as "one of the bugbears" or phantoms Jeffersonians used to "frighten the babes and old women." Equating propaganda about the junto to "gun-powder plots," he declared "The men whom they would designate as an Essex

Nichols, The Essex Junto; or Quixotic Guardian A Comedy in Four Acts By a Citizen of Massachusetts (Salem: Nathaniel Coverly, 1802), pp. 11, 12, 67-71.

${ }^{24}$ James E. Lewis Jr., " "What is to Become of Our Government?” The Revolutionary Potential of the Election of 1800 ," and Michael A. Bellesiles, "The Soil Will be Soaked With Blood': Taking the Revolution of 1800 Seriously," in James Horn, et al., eds., The Revolution of 180o: Democracy, Race, and the New Republic, (Charlottesville: University of Virginia Press, 2002), pp. 3-29, 59-86; Nichols, Essex Junto, pp. 45, 46, $49,52,53$.

${ }^{25}$ Nichols, Essex Junto, pp. 11, 53 . 
Junto, are as much interested in the preservation of a Republican government, as any men in the community, and would, by the introduction of a Monarchial government, dig a pit for their own destruction." 26 While Fessenden denied the existence of "an Essex Junto," rumors of conspiracy were not easily quashed and denials were even less effective when Federalists, through their own actions, transformed perceptions into reality.

Indeed, while Pickering did devise a plan for northern disunion following Jefferson's reelection in 1804, the call took on greater urgency during the embargo on all shipping that lasted from 1807 through 1809 . He and others claimed that the policy was part of a southern conspiracy to diminish New England's political influence and economic independence. Anti-embargo protests dovetailed with the Federalists' campaign to end the use of slaves in congressional representation and arrest the growth of southern political influence. Jeffersonians soon conflated these messages, which added a sectional dimension to the campaign against the Essex Junto. Democratic-Republican Nathaniel Ames, Fisher Ames's older brother, wrote that the "Northern States [are] nearly in open rebellion against Congress and Southern States." Since Jeffersonians were unwilling to repeal the embargo, disunion, argued the Federalist Newburyport Herald, was the only alternative to the Democratic-Republicans' legislative crusade to ruin New England's economy. When Congress finally repealed the policy, Federalist James Bayard of Delaware observed that lifting the embargo "was designed as a concession to our eastern brethren . . . that the union may still be preserved." ${ }^{27}$

Of course, Democratic-Republicans promulgated a very different interpretation. They asserted that the embargo failed

\footnotetext{
${ }^{26}$ Thomas Green Fessenden [Christopher Caustic, pseud.], Democracy Unveiled, or Tyranny Stripped of the Garb of Patriotism (New York: Riley \& Co., 1806), p. 74.

${ }^{27}$ Banner, Hartford Convention, pp. 115-16; Fischer, American Conservatism, pp. 175, 176; Ames quoted in Charles Warren, Jacobin and Junto or Early American Politics as Viewed in the Diary of Dr. Nathaniel Ames, 1758-1822 (Cambridge: Harvard University Press, 1931), p. 233; Newburyport Herald, 14 February 1806 and 14 March 1806 [Italics theirs]; James A. Bayard, Mr. Bayard's Speech Upon His Motion to Amend the Resolution Delivered in the Senate of the United States Tuesday, February 14, 1809 (Portland: Printed at the Gazette Office by Arthur Shirley, 1809), p. 17.
} 
because members of the Essex Junto seduced the unwary into violating and protesting the law as part of a scheme to dismantle the Union. The junto, after polluting all of New England had managed to rouse anti-embargo hostilities in the Mid-Atlantic States as well. Jeffersonian leaning newspaper correspondents retrieved language of the Revolution and denounced the Essex Junto as the heirs of Tories who advocated disunion, creation of a New England confederacy, and the restoration of monarchial government. ${ }^{28}$

William Bentley of Salem, an Essex County DemocraticRepublican, reflects the power of anti-junto propaganda in his diary. In 180o, Bentley mentioned the junto casually after noting its brief mention in a local newspaper. Between 1808 and 1809, however, as the Democratic-Republican press reported incidents of rabid protests and violations of the embargo, his disdain deepened. After reading of the Federalists' bellicose opposition to the embargo in the House of Representatives, Bentley added Josiah Quincy of Boston, to his personal list of Essex Junto politicians. When Bentley made this connection Federalists had not recaptured support in New England and decades would pass before Quincy would become the mayor of Boston and President of Harvard. Finally, riots and threats of disunion demonstrated that the crisis had reached a boiling point, and moved Bentley to grumble, "Nothing can exceed the effrontery of the party called the Essex Junto." 29

Years after the crisis over the embargo had passed and the presidency was behind him, Jefferson modified his views of the Essex Junto. While they all had an affinity for Britain, most of the Essex Junto, he now believed, did "not aim at separation."30 Jefferson never focused on exposing the identities of Essex Junto politicos because he presumed they were

\footnotetext{
${ }^{28}$ Fischer, American Conservatism, pp. 2-5, 249, 255. Paul Goodman, The Democratic-Republicans of Massachusetts: Politics in A Young Republic (Cambridge: Harvard University Press, 1964), p. 102.

${ }^{29}$ William Bentley, Diary of William Bentley, D.D. Pastor of the East Church Salem, Massachusetts, 4 vols. (Salem: Essex Institute, 1911), 2:343, 3:376, 415.

${ }^{30}$ Jefferson to John Melish, 13 January 1813, Jefferson Papers; Fischer, "Myth of the Essex Junto," pp. 231, 232.
} 
well known. Newspapers had described Fischer Ames as the "idol" of the Essex Junto and no one doubted that Pickering was its most highly placed member. ${ }^{31}$ But most DemocraticRepublicans considered all Federalists disunionists, and unlike Jefferson who never focused on specific identities of Essex Junto members, they felt the need to locate and chronicle such persons.

During one of several heated House debates over the embargo, John Wayles Eppes of Virginia, Jefferson's other sonin-law, became angry over the Federalists' revived popularity in New England. He harangued them for opposing the embargo but trained most of his fire on Senator Pickering, whose widely published anti-embargo letter to Massachusetts Governor James Sullivan undermined the policy. What was worse, complained Eppes, was that a sitting senator was also head of "a party connected and known under the name of the Essex Junto." Instead of being concerned, Pickering considered it a compliment to be included with other alleged members of the Essex Junto, and deemed it "my highest honor to have those gentlemen for my friends." ${ }^{2}$

Governor Sullivan, the recipient of Pickering's letter, sang loudly in the chorus of Essex Junto alarmists. After accusing Pickering of attacking the embargo to appease the British, Sullivan cautioned Jefferson, "I believe that the . . Essex Junto, commonly called federalists, here shall overthrow the present administration subvert the principles of the national government, [and] divide the Union." Earlier, the easily excitable Sullivan told James Monroe, then ambassador to Britain, that Bay State Federalists and their surrogates in Connecticut and New Hampshire were conspiring to divide the country into "three empires." Monroe tried to allay Sullivan's fears by assuring him that disunion plots "require only to be known to be defeated." At any rate, successful negotiations with Britain would expose

${ }^{31}$ Essex Register 27 May 1809; Banner, To the Hartford Convention, p. 43.

${ }^{32}$ Annals of Congress, 1oth Cong., 2d sess. 954; Timothy Pickering, A Letter From the Hon. Timothy Pickering ... (Portsmouth: William Treadwell, 1808); Pickering to George Henry Rose, Esq., 22 March 1808, Pickering Papers [Italics theirs]. 
any "artful \& unprincipled men at home" even those "in the first stages of the treason." But by the time Jefferson left office, more Democratic-Republicans sounded like Sullivan than Monroe and determined that Federalists' opposition to the embargo was a pernicious effort by the Essex Junto to destroy the republic. 33

Federalists charged President Madison and congressional Democratic-Republicans with initiating the War of 1812 despite a lack of preparation. This was the case, and DemocraticRepublicans had also resisted bipartisan solutions before the war and held Federalists responsible for protracting the conflict with Britain by criticizing their decision to declare war. The "Creed of the Essex Junto" claimed that Federalists had never been loyal to the United States, which is why they complained that "Madison can't do anything right." Yet, the problem for the junto, according to the Jeffersonian pamphlet, was "not that the president was a bungler, but that he was not an apologist for Britain and was not a Tory during the Revolution!" Essex Junto politicians were, which explains why they questioned the government's decision to go to war with Great Britain. ${ }^{34}$

Even though news traveled slowly, their stance during the war confirmed the Federalists' disloyalty in much of the country. Nevertheless, in New England the Madison Administration found it difficult, and in some areas impossible, to rally support for the war. Democratic-Republicans denounced the entire region and placed leading New Yorkers in the Essex Junto when they began to oppose the war. ${ }^{35}$ Nor did they forget Pickering, who along with his nephew, Samuel Williams, was at the center of a controversy for allegedly conferring with the British. The poem, Pickeroniad, dedicated "to all who are not such fools as

${ }^{33}$ James Sullivan to Thomas Jefferson, 2 April 1806, Jefferson Papers; James Monroe, The Writings of James Monroe, ed. Stanislaus Murray Hamilton 7 vols. (New York: AMS Press, 1969), 4:481-85; Jonathan Russell, The Whole Truth, or, the Essex Junto Exposed, (Boston: Office of the Public Advertiser, 1808), pp. 25, 27.

${ }^{34}$ Donald R. Hickey, The War of 1812: A Forgotten Conflict (Urbana: University of Illinois Press, 1995), pp. 19-28; "Creed of the Essex Junto," Independent Chronicle, 15 February 1810.

${ }^{35}$ City Gazette and Daily Advertiser 24 February 1810; Boston Patriot, 14 May 1814 . 
to be led by the Proboscis, the Essex Junto" charged antiwar Federalists with committing treason for monetary gain. As for Pickering, "[S]earch the page of ancient hist'ry through/so black a traitor will not meet your view." 36

The pamphlet Essex Junto and the British Spy; or, Treason Detected went even further when claiming that activities of the Essex Junto had been a justification for the war. Comprised of "a body small in numbers but powerful in talents, wealth and intrigue," junto leaders were "bent on the subversion of civil liberty, to secure themselves crowns and titles of nobility, regardless of the consequences to severing the Union." William Duane, editor of the Philadelphia Aurora and Tammany Hall Jeffersonian Benjamin Romaine heaped similar denunciations on the Essex Junto for wartime perfidy. ${ }^{37}$

Federalists had planned to and did weaken the nation's war effort because they questioned the governing party's motives for war from the beginning. Suggestions from Pickering and others that New Englanders should negotiate a separate peace with Britain to preserve the older regions of the Union by separating them from new states and territories in the West confirmed that the danger of disunion was ever-present. If left unchecked the Essex Junto could reverse the results of the Revolution. To a majority of Americans, dissension during the War of 1812 demonstrated the depths to which the Essex Junto would sink to destroy the Union. ${ }^{8}$ It also proved that their swelling angst over the Union's survival was justified.

Madison won reelection in 1812 despite the fact that Federalists joined dissident Democratic-Republicans in New York, New Jersey, and Delaware to support DeWitt Clinton (N.Y.).

\footnotetext{
${ }^{36}$ Jefferson to John Adams, 20 April 1812, Jefferson Papers; Ralpho Risible [pseud.], The Pickeroniad: or Exploits of Faction . . . (Newburyport: Wright, 1811), pp. 12, 17, 35, 36 [Italics theirs].

${ }^{37}$ John Henry, The Essex Junto and the British Spy: or Treason Detected (Salem: n.p., 1812), p. 2; William John Duane, The Law of Nations, Investigated in a Popular Manner, (Philadelphia: Printed by William Duane, 18og), p. 631; Benjamin Romaine, Tammany Society, No. 1, Twenty-fourth Anniversary Address, New York, Season of Bloom, 12th May, 1813 (New York: n.p., 1813), p. 10.

${ }^{3} 8$ Banner, Hartford Convention, 110, 112; Hickey, War of 1812, pp. 159-81; Russell, Whole Truth. p. 25.
} 
The election results were not close ( 128 to 89 electoral votes), but considering the fact that Madison was a wartime president whose major challenger was from the same party, Clinton came too close for comfort. Before the election Clinton criticized Jefferson, Madison, and southerners in Congress for taking out their hostilities against the commercial north through the embargo and other trade restrictions. His uncle, George Clinton, Jefferson's vice president and a former governor of New York, shared this opinion, insisting that the Virginians' chief concern was not protecting commerce, but keeping slaves "from cutting their Masters throats." A good number of Federalists threw their support behind Clinton, the "peace party" candidate. When he accepted their endorsement, Steven Edwin Siry points out, the alliance precipitated "the bitter climax of his national political aspirations and the beginning of Clinton's unjustified obscurity and denigration in American political history."39

For this act of apostasy, Madison's supporters labeled Clinton the "New-York and Essex Junto candidate." ${ }^{\circ}$ In an article questioning his patriotism, the Richmond Enquirer dispraised Clinton, calling him "a catspaw in the hands of the Essex Junto" who would destroy the Union if elected. DemocraticRepublicans attacked Clinton nationwide for fraternizing with Federalists. "It is currently said, as we have understood in federal articles in New-England, that if they could gain the co-operation of the state of New York they would recede from the Union; Is it not the great object of the Essex Junto in supporting Mr. Clinton to gain this Co-operation?" asked Charleston's City Gazette. ${ }^{41}$

${ }^{39}$ Clinton quoted in Leonard Richards, The Slave Power: The Free North and Southern Domination, 1780-186o (Baton Rouge: Louisiana State University Press, 200o), pp. 63-67; Siry, "Sectional Politics," pp. 455-58; Hickey, War of 1812, pp. 100-105.

$4^{\circ}$ Annals of Congress, 12th Cong., 2d sess. 256; Steven Edwin Siry, "Sectional Politics of 'Practical Republicanism': De Witt Clinton's Presidential Bid, 1810-1812," JER 5 (Winter 1985): 441-62.

${ }^{41}$ Public Advertiser [NY], 26 August 1812; for similar comments see, Pittsfield Sun or Republican Monitor, 22 October 1812; Richmond Enquirer, 21 August 1812; City Gazette and Daily Advertiser [Charleston], 11 September 1812. 
Clinton previously condemned the Essex Junto and Federalists in general for allegedly colluding with "the British Ministry" on a regular basis. Like Milton's fallen angel Beelzebub, the junto considered it "better to reign in hell than serve in heaven." Unable to win an election "through honest means," junto affiliates would rather "regain office and elevation through blood, destruction, and general ruin than not to obtain them at all." It was not until his plans clashed with those of his party's southern leadership that former colleagues unearthed the deep-rooted "intrigues" that they claimed Clinton had been perpetrating his entire career. "If any doubt remains of the truth of the character . . of De Witt Clinton," wrote one editorialist, "you have a confirmation of it . . in the unhallowed Union he has formed with the federalists. He pretends to be a republican, and yet is supported by the Essex Junto, who but yesterday plotted the separation of the states." Out of blind ambition, Clinton chose to "rule in hell" with the rest of the Essex Junto. ${ }^{42}$ Also clear, was the fact that the Essex Junto and its evil designs would no longer apply exclusively to dissidents from Massachusetts, New England, or the Federalist Party.

Including members of Jefferson's party in the Essex Junto did not mean that young, antiwar Federalists such as Josiah Quincy would escape the Democratic-Republicans' ire. In January 1813, Speaker of the House, Henry Clay of Kentucky seized the opportunity to harangue Quincy during debates over military appropriations. Quincy, one of the most provocative embargo and war opponents in the House, accused DemocraticRepublicans of swaying public opinion against Britain in order to hold onto seats in Congress, keep the "Monticellian dynasty" in the presidency, and justify the allocation of funds for an ill-conceived war. Clay rebuked Quincy for spouting views of the "pack set loose from the Essex kennel." He was not

\footnotetext{
${ }^{42}$ De Witt Clinton, Speech of the Hon. De Witt Clinton, in the Senate of the State of New York, on Tuesday January 31, 1809 . . (New York: Henry C. Southwick, 1809), pp. 17-19; Essex Register, 18 March 1809; National Advocate [New York], 21 October 1819; Milo [pseud.], Letters Addressed to a Friend at Pittsburg on the Character and Conduct of De Witt Clinton, Esq. (New York: Ptd. \& Pub., 1812), pp. 5-8, 15.
} 


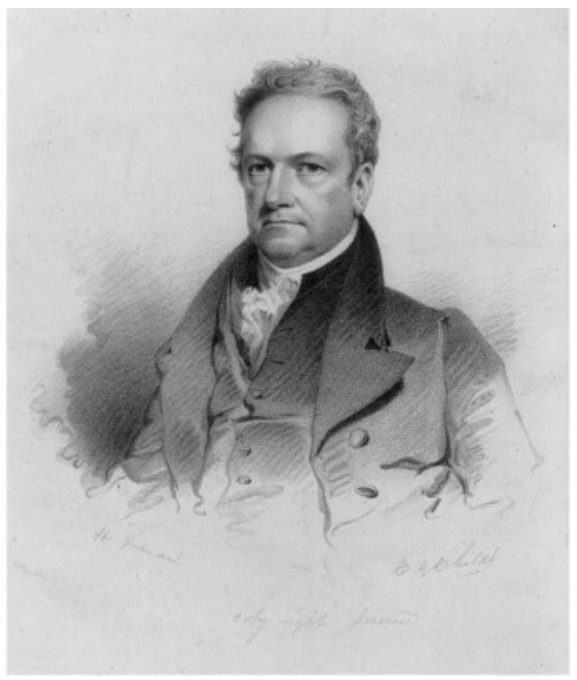

Dewitt Clinton (1769-1828)

Generally remembered for the Erie Canal while governor of N.Y. (1817-23 and 1825-28), Clinton ran for president in 1812 as a DemocraticRepublican with Federalist support and was associated with the Essex Junto and the disunionism that he previously rejected. Courtesy of the U.S. Senate Historical Office, Library of Congress.

from Essex County, but Clay predicted that Americans would inscribe Quincy "in the treasonable annals of a certain junto . . conspirators against the integrity of the Union."43

Quincy often mentioned disunion as a possible consequence for the sectional hostility that Democratic-Republicans accompanied the passage of restrictions on maritime trade and the war. He consistently championed New England's interests and corresponded with Fisher Ames and Timothy Pickering while in Congress, but never dictated or controlled the Federalist Party. On the contrary, it was not unusual for him to act against the advice of Federalists colleagues, such as when he proposed and then cast a single vote to impeach Jefferson. To political

${ }^{43}$ Annals, 12th Cong., 2d sess. 552, 553, 564; Henry Clay, The Papers of Henry Clay, eds. James F. Hopkins and Mary W. M. Hargreaves, 11 vols. (Lexington: University of Kentucky Press, 1959) 1:759-83. 
adversaries like Clay opposition to the embargo and criticisms of Jeffersonians left no doubt that Quincy was a degenerate, disloyal politician who was by all appearances affiliated with the junto. After the war Democratic-Republicans continued to invoke the illusive Essex Junto to silence dissent. In 1820, Clay complained that "the predilection of the school of the Essex Junto for foreign trade and British Fabrics" fostered opposition to a tariff bill. Even though the Federalist Party was beginning to deteriorate, as in the past, Clay found it convenient to summon the Essex Junto in order to discredit an opponent. This time it was Massachusetts Federalist Ezekiel Whitman. ${ }^{44}$

No matter how often Democratic-Republicans used the Essex Junto to turn public opinion against them, Quincy, Pickering and other Federalists refused to scale back their opposition to the war, stifle threats of disunion, or allow Democratic Republicans to operate with impunity. Yet, moderate Federalists like Harrison Gray Otis of Boston moved to distance themselves from the radicals. Otis denied that the Essex Junto existed and dismissed rumors that "an Essex or a Boston Junto" controlled the Federalist Party as "eternal nonsense." But in spite of plans to advance his career in national politics, it was difficult to erase decades of conspiracy theories, and then impossible when Otis and other Federalists participated in the Hartford Convention. Though insisting that he took part in the convention to ease potentially riotous tensions in Massachusetts, neither Otis nor any other Hartford Convention delegate could escape the stigma of Essex Junto disunionism. ${ }^{45}$

Throughout its history the Essex Junto was a bugbear at best, but to political opponents the Hartford Convention confirmed that Federalists had been involved in the "treasonable practices of the Essex Junto." On the eve of the convention in December 1814, U.S. minister to France William H. Crawford, a Democratic-Republican from Georgia, expected

\footnotetext{
${ }^{44}$ Annals, $9^{\text {th }}$ Cong., $1^{\text {st }}$ sess. 1035-42, 1oth Cong., 2 d sess. 1173-82, \& 16 th Cong., 1st sess. 2049, 2050; Clay, Papers, 1:759 \& 2:843; Robert A. McCaughey, Josiah Quincy, 1772-1864: The Last Federalist (Cambridge: Harvard University Press, 1974), pp. 5456.

45 Banner, Hartford Convention, pp. 51, 303, 354.
} 
"Boston editors ... [ [who] promulgate the views of the Essex Junto" to sway Americans against the war. Crawford, a future Secretary of the War and Treasury departments was convinced that the situation was ripe for the Essex Junto, even if largely confined to New England, to destroy the Union. ${ }^{4}$

In an effort to put a less menacing face on the Hartford Convention, organizers banned hotspurs such as Pickering and Quincy from open participation. However, the precaution proved ineffective against charges of conspiring against the government. The Baltimore Patriot and Evening Advertiser reported that Convention delegate George Cabot, who other Federalists considered a moderate, had been "a distinguished member of the Essex Junto" for some time. The Patriot then said that the Hartford Convention delegates assembled "with the ingenuity of a malignant band of savages and cutthroats." But that was just the beginning. One of the Convention's resolutions called for repeal of the three-fifths clause. For issuing a demand pertaining to slavery, the Alexandria Herald said if the Essex Junto held its Convention "in any other country than this," its participants "would have been punished as traitors." 47

When the Hartford Convention linked all of the New England states to the Federalists' condemnation of the three-fifths clause, the junto experienced the final evolution in its development. Northerners' growing opposition to slavery created a new reason for politicians to evoke the Essex Junto. As opposition to slavery and its expansion into new western territories escalated, northern Democratic-Republicans were at the forefront of antislavery politics. Apathetic or prosouthern New Yorkers saw this as proof that the Essex Junto had finally managed to infiltrate and divide their party. In fact, the growth of abolitionism moved many to assert that the junto had corrupted every northern and northwestern state. Lines needed to be drawn, and any political "amalgamation" with Federalists or

\footnotetext{
${ }^{46}$ William H. Crawford to Henry Clay, December 12, 1814, William Harris Crawford Papers, The Filson Historical Society, Louisville, Ky.

${ }^{47}$ Baltimore Patriot and Evening Advertiser, 30 November 1814; Baltimore Patriot, 5 June 1815; The Alexandria Herald, 9 October 1815.
} 
anyone expressing their divisive sentiments regarding slavery rejected..$^{8}$

Clinton's alliance with Federalists had represented more than the transgressions of a powerful New York politician just as the Hartford Convention transcended the radicals' antiwar protests. Both signaled the likelihood that northerners regardless of political affiliation would unite to fight the spread of slavery and growth of southern political power. Southerners understandably found the prospect troubling. Too many northerners already seemed to concur with Federalists that the three-fifths clause was unjust and the spread of slavery a threat to liberty. 49 Proslavery politicians, North and South, condemned any movement involving the abolition of slavery or placing limits on its expansion as a threat to the Union instigated by the Essex Junto.

As far back as 1808 , a few months before his death, Governor Sullivan charged Federalists with attacking slavery in order to separate New England from the slaveholding states, and leave the South "to provide for its Negroes" alone. Congressional Federalists had opposed slavery's expansion into new territories well before the issue finally exploded during debates over Missouri's admission into the Union. The problem originated when New York Democratic-Republican James Tallmadge, who also happened to be a Clintonite, proposed banning slavery from Missouri as a condition for statehood. Southerners responded with threats of disunion and allegations that Tallmadge's proposal originated with the Essex Junto. The Albany Angus claimed that the Essex Junto initiated the Missouri crisis to spark "serious contention between the northern and southern interests, which would terminate in a separation of the states." 50

By this time, however, the Bucktail faction of New York Democratic-Republican Party, led by future president Martin

\footnotetext{
${ }^{48}$ Weekly Aurora [Philadelphia], 13 July 1818.

${ }^{49}$ Republican Watch-Tower [N.Y.], 13 September 1808; Albany Argus, 18 April 1820.

${ }^{50}$ James Sullivan to Jefferson, 2 and 5 April 1808, Jefferson Papers; Daniel Walker Howe, What Hath God Wrought: The Transformation of America, 1815-1848 (New York: Oxford University Press, 2007), p. 147; Albany Angus, 18 April 1820.
} 
Van Buren had wrested control away from the Clintonites. In Congress, Bucktails voted consistently with the South and tried to silence opponents of slavery by connecting them to the Essex Junto. New York Federalists responded that they had never been part of the Essex Junto. Just as Bucktails did not speak for all Democratic-Republicans, if the Essex Junto existed, it did not represent every Federalist. ${ }^{51}$ Nonetheless, southerners and their northern supporters continued to accuse the Essex Junto of sparking the Missouri controversy to disrupt sectional harmony as it did during Jefferson's presidency. As tensions mounted, Daniel Webster and other New England Federalists submitted a memorial to Congress demanding that slavery be excluded from Missouri and every new state entering the Union thereafter. As a consequence, the Portsmouth Gazette accused Webster of conspiring with the Essex Junto and asserted that for this reason he could not be trusted. ${ }^{52}$

Before entering Congress in 1813, Webster had been an ardent opponent of Jefferson's embargo. He questioned its constitutionality and published accusations that DemocraticRepublicans never intended for the embargo to protect commerce. Then, during the War of 1812 , Webster was at the forefront of a congressional investigation that examined the validity of evidence used as the basis for declaring war in 1812. Later in his career Webster became a Whig, was appointed secretary of state by three presidents, and notoriously supported compromises on the spread of slavery in order to preserve sectional harmony. 53

Webster appeared to repudiate his Federalist past. Northerners who once applauded his audacity complained that Webster

\footnotetext{
${ }^{1}$ Richards, Slave Power, pp. 120-27; Columbian [N.Y.], 20 August 1819, and 18 October 1820 .

${ }^{52}$ Franklin Monitor and Middlesex Republican, 18 March 1820; Albany Argus, 18 April 1820; Portsmouth Gazette, 4 January 1825; Daniel Webster, et al., Memorial to the Congress of the United States, on the Subject of Restraining the Increase of Slavery in New States to be Admitted into the Union (Boston: Sewell Phelps, 1819), pp. 4, 6-8.

${ }^{53}$ Daniel Webster, Consideration of the Embargo Laws (Boston: n.p., 1808), pp. 4-6; J.C.A. Stagg, Mr. Madison's War: Politics, Diplomacy, and Warfare in the Early American Republic 1783-1830 (Princeton: Princeton University Press, 1983), pp. 304309; Richards, Slave Power, pp. 110, 111; David Potter, The Impending Crisis, 18481861 (New York: Harper \& Row, Publishers, 1976), pp. 101-102.
} 
had become an advocate for the South and should not count on getting support from either section of the country. ${ }^{54}$ Overall, the past haunted Webster from both sides, but most often from Democrats or Democratic-Republicans. Despite shedding his radicalism and adopting a nationalist image during his run for president as the Whig Party candidate in 1835 , the RhodeIsland Republican could not let the past die. While "the Godlike senator of Massachusetts" might be considered great by some voters, "So was Timothy Pickering, so is Harrison Gray Otis and many others of that renowned fraternity, the Essex Junto." The paper predicted that Webster's support would come solely from Massachusetts, and then only from "Hartford Convention and Essex Junto Federalists." As predicted, when the election of 1836 was over, Webster's only electoral votes came from Massachusetts. For several years after the election, political foes would revive the Essex Junto to make sure that Americans would never forget his past and allow Webster to become president. 55

Webster had called slavery a moral evil during the conflict over the embargo, and the junto followed him for the rest of his career. He was dubbed "tool" and "head of the Essex junto," and part of the junto through "breeding and adhesion," well into the 1840s. Any supporters of the National Republicans or Whigs were included in denunciations of Webster. Proslavery politicians branded those who opposed the spread of slavery Essex Junto disunionists, but during the next four decades, northern politicians found it increasingly difficult to win elections if they openly supported the spread of slavery. Former New York governor Daniel D. Tompkins, James Monroe’s Vice President, was forced to refute charges that he was pro-slavery. Supporters brandished his antislavery credentials and boasted that at one time Tompkins recommended "absolute abolition"

${ }^{54}$ Jabez D. Hammond, A Letter to the Hon. Daniel Webster [Dated March 20 , 1850, on Slavery] (Cherry Valley: Gazette Office, 185o), pp. 4, 6-8; An unsigned copy is located in the Martin Van Buren Papers, Library of Congress.

55 Rhode-Island Republican, 28 January 1835; New-Hampshire Patriot and State Gazette, 30 April 1827 and 23 April 1841; U.S. Congress, Senate Journal, 24th Cong., $2 \mathrm{~d}$ sess., 8 February 1837, p. 227; The Ohio Statesman, 29 September 1840. 
in New York, and "relieved whole families of colored people from slavery, by purchasing their freedom." 56

Clearly, the Essex Junto continued to surface in political discourse and propaganda long after the Federalist Party disbanded in 1824. Southern and northern Democrats held the Essex Junto responsible for deepening northern hostility to slavery. As several threads of antislavery sentiment combined to form the Liberty and Free Soil parties, including free labor advocates and political abolitionists, northern voters began to elect antislavery politicians to state and national offices. Tensions in Congress thickened when representatives or senators criticized slavery, even in abstract terms, and southerners still blamed the Essex Junto for causing the sectional divide. ${ }^{57}$ In this climate, even John Quincy Adams who parted with Federalists over the embargo could not escape involuntary induction into the Essex Junto. As the presidential election of 1824 drew near, Andrew Jackson, southerner by birth, westerner by choice, and an expansionist slaveholder through ingenuity, was the popular favorite. Adams, on the other hand, was a former Federalist, and Jackson's supporters could breed mistrust based on his former political affiliations. In no time they dubbed Adams, "poet Laureate to the Essex Junto." $5^{8}$

Adams was annoyed that "newspapers of extensive circulation published in various parts of the Union acting in close concert with each other" were "pouring fourth continual streams of slander upon my character and reputation, public and private." Friends in New England tried to distance him from the propaganda by casting his election as a unifying event. Democratic-Republican and former Secretary of the Navy, Benjamin Crowninshield, ironically a resident of Salem in Essex County, received a letter expressing the importance of

\footnotetext{
${ }^{6}$ New Hampshire Gazette, 4 January 1825; Eastern Argus, 18 December, 1827; New Hampshire Patriot and State Gazette, 18 August 1834; Albany Argus, 18 April 1820 [Italics theirs]; Wiskonian Enquirer, 13 March 1841; New-Hampshire Patriot and State Gazette, 1 December 1842.

${ }^{57}$ Richards, Slave Power, pp. 134-38; Howe, What Hath God Wrought, p. 652.

${ }^{5}$ Essex Register, 11 September 1823; Augusta Chronicle and Georgia Advertiser, 18 June 1823; Independent Chronicle and Boston Patriot, 7 May 1823; Eastern Argus [Portland], 18 October 1824 .
} 
an Adams' victory. If John C. Calhoun of South Carolina and Andrew Jackson "are friendly to a union of the Republican Party \& wish to defeat the intrigues and effects of the radicals" the letter admonished that they stop opposing Adams and the "cause of the North." Adams won every New England state except Vermont, and received 26 of New York's 36 electoral votes. Following his lackluster presidency, he lost his bid for reelection in 1828. But even in defeat Adams won every New England State, 16 of New York's votes, and carried New Jersey, Delaware, and Maryland—states that he lost in 1824.59

One of Adams's many mistakes during his presidency was offering Dewitt Clinton the ambassadorship to Great Britain and then appointing Federalist Rufus King to the post when Clinton declined. King's appointment gave Adams's enemies enough information to claim that he was colluding with the Essex Junto. Even after his loss to Jackson, Democrats insisted that both John Quincy and his father had been in bed with the Essex Junto. At times, the Democratic press even accused slaveholders such as Henry Clay, William Henry Harrison, and Zachary Taylor of being pawns of the Essex Junto. Before the 1840 election, Democrats described Harrison as "pretty much of a granny," who had "silly notions about Negroes." They claimed everything his Federalist supporters, like Josiah Quincy, had done since Jefferson's election was meant to turn Americans against the slave South. Democrats associated Harrison with the Essex Junto but failed to bring about his defeat. They did, however, show a propensity for exploiting Americans' fears to preserve slavery and win elections. ${ }^{60}$

${ }^{59}$ John Quincy Adams, The Diary of John Quincy Adams, 1794-1845, ed. Allan Nevins (New York: Charles Scribner's Sons, 1951), p. 327; Independent Chronicle and Boston Patriot, 22 October 1824; Statesman [Newburyport], 22 August 1808; Independent Federalists of Lincoln, Congressional Election September 8, 1823 . . Broadside Collection, American Antiquarian Society, Worcester, Mass.; M. Corham[?] to Benjamin Crowninshield, 17 July 1824, Crowninshield Family Papers, Philips Library, Peabody Essex Museum, Salem, Mass.; Annals, 18th Cong., 2d sess. 149 and 2oth Cong., 2 d sess. 120.

${ }^{60}$ Hartford Times, 21 May 1832; Macon Georgia Telegraph, 15 October 1839; Pittsfield Sun, 17 September 1840; Macon Georgia Telegraph, 15 October 1839; Howe, What Hath God Wrought, pp. 146, 147; New-Hampshire Patriot and State Gazette, 18 August 1834 and 12 October 1848 . 
By the 1830 , the mainstream politicians most susceptible to Essex Junto propaganda belonged to the Whig Party, because many of its members were former Federalists and anti-Jackson Democrats. After becoming a Whig, Henry Clay's words came back to haunt him as his former party mates lumped him in with the "kennel of the Essex Junto," and when the new party rose in prominence, they were disparaged as "the same men under a new name . . . trying to secure the aid of abolitionists against the South." If they supported Whigs or belong to the party, even southern and western Whigs could count on identification with the junto and those who "called for disunion or abolition." ${ }^{\prime 61}$

As the national debate over slavery intensified, Democrats announced, "The Essex Junto are yet alive!" If the South seceded, their contention was that the junto was to blame. Several newspapers including the Daily Missouri Republican argued that the "doctrine of the right of secession originated with the Essex Junto." The Pittsfield Sun rationalized that northern abolitionism, which instead of slavery was tearing the nation apart, was also a creation of the Essex Junto and Hartford Convention. Politicians of this ilk, the Sun continued, "were the first disturbers of the Constitutional Compromise," the three-fifths clause, and had "called for disunion or [the] abolition of slave representation . . . as the modern Abolitionists do now." When making a similar comparison, the mordant article, "A Bad Breed of Children to Adopt" published in the Barre Gazette, declared that leading abolitionist Wendell Phillips had merely "taken up and clothed the apparently discarded intellectual children of . . . the Essex Junto." 62

Try as they might Democrats could not discredit the antislavery politicians by attacking them with the Essex Junto. Americans could plainly see that despite northerners' willingness to

${ }^{61}$ The Hartford Times, 21 May 1832; Macon Georgia Telegraph, 15 October 1839; Pittsfield Sun, 17 September 1840.

${ }^{62}$ Eastern Argus [Portland], 1 March 1831; Elizabeth R. Varon, Disunion!: The Coming of the American Civil War, 1789-1859 (Chapel Hill: The University of North Carolina Press, 2008), pp. 32, 33; Daily Missouri Republican, 14 January 1851; Pittsfield Sun, 17 September 1840; Barre Gazette 18 June 1847. 
accept compromises and gag rules, southerners, amid violent outbursts were the ones threatening to secede from the Union, and did so to protect slavery. By referencing the Essex Junto, Democratic-Republicans successfully defamed New England's dying Federalist Party, but by the late 1840s, the opponents of slavery had a broad, expanding base of support. With attacks on slavery emanating from almost every region of the nation except the South, attempts to intimidate antislavery politicians by evoking the Essex Junto were futile. More than half of the United States was developing an antipathy towards slavery that had once condemned the junto. When this transformation took place the Essex Junto no longer induced panic or damaged political careers as it had in the past.

Secession and civil war ended both chattel slavery and the three-fifths clause. Still, the Essex Junto managed to limp into the literature of the post-Civil War years. The term surfaced in books, newspapers and journal articles, but without its former relevance. This was obvious during Reconstruction, when the Idaho Tri-Weekly Statesman asked, "Why should the conspiracy of the Calhoun Junto (secession) bring greater punishment on its innocent victims than the Essex Junto and its Hartford Convention?" ${ }^{3} 3$

When Congress began to archive its public records at the end of the nineteenth century, it attempted to define the Essex Junto. Despite its long and diverse history, however, the government determined that the term was a "synonym for New England Federalism.” Ames, Cabot, Lowell, Higginson, and Pickering are listed "among prominent members of the Essex Junto," and John Quincy Adams is counterpoised as a critic of junto "policy and principles." Among these policies was a strong central government and "protection of the commercial interests of the country." But the archive fails to explain why the politicians, propagandists, and political writers of the period connected Josiah Quincy, John Adams, Harrison Gray Otis, John Quincy Adams, DeWitt Clinton, and Daniel Webster to

\footnotetext{
${ }^{6}$ Galveston Flake's Bulletin, 2 May 1866; Idaho Tri-Weekly Statesman, 24 April 1866.
} 




Daniel Webster $(1782-1852)$

Webster of N.H. entered Congress as a Federalist (1813-16), relocated and represented Mass. in the House and Senate $\left(1823^{-50}\right)$. Webster ran for president as a Whig in 1836 when former association with the Federalist Party linked him to the Essex Junto. Courtesy of the U.S. Senate Historical Office, Library of Congress.

the Essex Junto. ${ }^{6}{ }^{6}$ The government's most startling omissions are the disunionism, repeal of the three-fifths clause, and antislavery politics that politicos ascribed to the Essex Junto.

Attempts to classify the Essex Junto with secret societies, like the Illuminati and Freemasons help to explain why its significance was lost by the early twentieth century. While it provided no explanation, an article looking at historic presidential tours of the nation concluded that encountering the Essex Junto was the major difference between the tours taken by Presidents McKinley and Taft, and those of Monroe and Jackson. Six

${ }^{64}$ James D. Richardson, The Compilation of the Messages and Papers of the Presidents, 1789-1897 20 vols. (Washington, D.C.: Government Printing Office, 1899), 10: $35^{\circ}$. 
decades later, the junto resurfaced in a 1968 piece about antiVietnam War protests. The article concluded that at one time the Essex Junto posed a more serious threat to the nation than Vietnam War protesters. ${ }^{65}$ Although this conclusion is essentially correct, because no single group of politicians formed the Essex Junto, references to the reveals the term's longevity as a critique of politicians who espoused controversial positions.

What these writings overlook is the relationship between the insecurities and fears that sired the Essex junto and the controversies that gave it its vitality. From the beginning, the junto was shaped by anxieties over preserving republican government and the Union. Suspicions of disloyalty were easily cast upon politicians who represented the same economic class and region, especially when they expressed similar perspectives and voted the same way in Congress. As Robert Treat Paine of Massachusetts explained in 1776 , it only took " 2,3 , or 4 men" appearing to vote uniformly to convince members of the Continental Congress that a junto was poised to destroy "everyone who will not comply with their mode of conduct."66 The Essex Junto tapped into Americans' fears and surfaced like a monster springing from the shadows in times of adversity. Though no single Essex County politician controlled the Federalist Party, what the Essex Junto symbolized was very real in Americans' minds and experiences. At key intervals after the Revolution the republic was in jeopardy, but in the end survived secession and civil war. Through its frequent appearances in sensationalized speeches, prose, and poetry during the most dynamic periods in U.S. history, the Essex Junto emerged as a testament to political uncertainty.

Even though it transcended geographic boundaries, traversed partisan divides, and experienced modifications over time, the Essex Junto never lost its original contours. Politicians resuscitated the Essex Junto when they needed to strike fear in the

\footnotetext{
${ }^{6}$ Morning Herald [Lexington], 12 May 1901; San Jose Mercury Evening News, 18 October 1909; Sunday Herald Traveler [Boston], 29 September 1968.

${ }^{66}$ Fischer, American Conservatism, p. 235; Hofstadter, Paranoid Style, p. 11; Robert Treat Paine to Joseph Palmer 1 January 1776, Letters of Delegates, 3:11.
} 
public mind to silence opposition to unpopular policies, end antiwar protests, or halt the spread of antislavery sentiment. Yet, each time it resurfaced those associated with the Essex Junto grew more impenitent and references to the junto proved less provocative. As the spread of slavery united Americans against an insidious, real enemy, politicians embraced the attributes that identified the Essex Junto without apologizing. Voters disregarded attempts to smear antislavery candidates with Essex Junto propaganda, and many praised Federalists for their uncompromising spirit. In the end, we can understand the Essex Junto as a propaganda tool, the excrescence of a polity in flux, and a reflection of fundamental flaws in the republic that could not be diminished passively. ${ }^{67}$

${ }^{67}$ McInnis and Nelson, Shaping the Body Politic, p. 37.

Dinah Mayo-Bobee received a Ph.D. in U.S. history from the University of Massachusetts Amherst in 2007. Currently an assistant professor at East Tennessee State University, she is at work on a book-length monograph on Federalist Party politics in the Age of Jefferson. 